\title{
Peran Insektisida Botani Ekstrak Biji Mimba untuk Konservasi Musuh Alami dalam Pengelolaan Serangga Hama Kapas
}

\author{
DWI ADI SUNARTO DAN NURINDAH \\ Balai Penelitian Tanaman Tembakau dan Serat \\ (diterima Desember 2008, disetujui Februari 2009)
}

\begin{abstract}
Natural Enemies Conservation: The Role of Neem-seed Extracts for Natural Enemies Conservation Used of Cotton Insect Pest Control. Insects associated with cotton plant are numerous, as the plant bears extrafloral nectar. More than 90 species of natural enemies are reported and identified. They could manage the cotton pest, keeping the pest population is under action threshold level when their presence is considered in scouting and action threshold concept. However, most of cotton farmers are insecticide-spray-minded people who think that insecticide sprays is a must in cotton cultivation. This behavior is unfavorable for the natural enemies in building their population so they can act as an effective mortality factor for the pest. Neem seed extract (NSE) is toxic to herbivores but relatively safe for natural enemies, so that it could be used as a substitute for synthetic chemical insecticides. Therefore, NSE is recommended to be used for conserving natural enemies in cotton agro ecosystem.
\end{abstract}

KEY WORDS: neem seed extract, Gossypium hirsutum, conservation

\section{PENDAHULUAN}

Serat kapas merupakan bahan baku utama pada industri tekstil, selain rayon viscosa dan serat buatan. Kebutuhan serat kapas dari tahun ketahun terus meningkat seiring dengan peningkatan produksi tekstil. Namun sebaliknya, pasokan serat kapas dari dalam negeri justru cenderung menurun. Pada tahun 2008 Indonesia menduduki peringkat pertama sebagai konsumen terbesar serat kapas dunia dengan volume impor 732.015 ton dengan nilai 1,2 milyar dollar AS (Anonim 2009). Ironisnya, pasokan bahan baku serat kapas dalam negeri untuk industri tekstil hanya $0,54 \%$.

Pengembangan tanaman kapas dalam negeri, baik melalui program intensifikasi maupun ekstensifikasi, sangat lamban. Salah satu penyebab lambannya pengembangan ini adalah adanya anggapan bahwa pada tanaman kapas terdapat banyak hama, sehingga memerlukan biaya yang besar untuk pengendaliannya, yang akhirnya berakibat pada rendahnya daya saing komoditas.

Tanaman kapas memiliki extra floral nectar, sehingga disukai oleh 
serangga. Serangga-serangga tersebut tergolong jenis serangga fitofag yang memakan bagian tanaman kapas dan serangga berguna (serangga penyerbuk, parasitoid, predator, dan lain-lain). Serangga fitofag berasosiasi dengan tanaman kapas tidak kurang dari 62 spesies teridentifikasi (Nurindah \& Indrayani 2002). Dari kelompok serangga fitofag tersebut, tiga spesies yaitu wereng kapas Amrasca biguttula (Ishida), penggerek buah kapas Helicoverpa armigera (Hubner), dan penggerek buah merah jambu Pectinophora gossypiella Saunders, dianggap sebagai serangga hama yang paling merugikan. Ketiga jenis serangga hama ini menyerang sepanjang umur tanaman kapas mulai tanaman muda hingga tua, bahkan $P$. gossypiella dapat terbawa hingga di gudang penyimpanan. Walaupun demikian, jumlah serangga yang teridentifikasi sebagai musuh alami lebih banyak dibanding jenis serangga fitofag, yaitu tidak kurang dari 51 spesies parasitoid dan 40 spesies predator (Nurindah \& Indrayani 2002). Dengan keanekaragaman musuh alami yang cukup tinggi tersebut, maka agroekosistem kapas berpeluang cukup tinggi untuk dapat terjaga dari terjadinya ledakan populasi hama.

Pengembangan pengendalian hama secara terpadu (PHT) pada kapas yang menekankan pada pemanfaatan musuh alami merupakan suatu solusi yang baik dalam pengembangan kapas, karena jika sistem ini diterapkan dengan benar, mempunyai keuntungan ekonomis, ekologis, maupun sosial (Nurindah \& Mukani 2006). Peran musuh alami sebagai faktor mortalitas biotik serangga hama terbukti efektif dan dapat menekan biaya pengendalian hama pada tanaman kapas (Nurindah et al. 2006). Optimalisasi peran musuh alami dapat dilakukan dengan merencanakan dan mengarahkan semua aktivitas dalam usaha tani kapas pada tindakan yang dapat mengkonservasi musuh alami. Penggunaan insektsida kimia sintetik yang tidak aman terhadap musuh alami merupakan kendala utama dalam konservasi musuh alami pada tanaman kapas. Karena itu, pemilihan dan penggunaan jenis insektisida yang aman terhadap musuh alami adalah tindakan yang tepat dalam upaya memberikan peran pada musuh alami sebagai faktor mortalitas biotik yang efektif pada pertanaman kapas. Insektisida ekstrak biji mimba (EBM) merupakan salah satu insektisida organik yang telah dikembangkan untuk digunakan pada pertanaman kapas (Nurindah \& Sunarto 2008a). Makalah ini membahas peran insektisida EBM dan strategi pemanfaatnya untuk tujuan konservasi musuh alami pada pertanamanan kapas. Makalah ini merupakan tinjauan hasilhasil penelitian tentang EBM yang diaplikasikan pada pertanaman kapas dan hubungannya dengan musuh alami serangga hama kapas. 
MIMBA (AZADIRACHTA INDICA

\section{A. JUSSIEU)}

Mimba Azadirachta indica A. Jussieu tergolong dalam famili Meliaceae. Tinggi pohon berkisar antara $10-25 \mathrm{~m}$, batang tegak berkayu, daun majemuk, yang letaknya berhadapan dengan panjang 5-7 $\mathrm{cm}$ dan lebar 3-4 cm, biji bulat panjang dengan diameter $0,5 \mathrm{~cm}$ dan panjang $1 \mathrm{~cm}$ berwarna putih. Tanaman mimba berasal dari Asia Selatan dan Tenggara. Saat ini tanaman mimba dijumpai di daerah tropik dan sub tropik Afrika, Amerika, dan Australia. Beberapa negara mengintroduksi tanaman mimba untuk keperluan sebagai tanaman hutan, tanaman pinggir jalan, tanaman peneduh, dan tanaman penghasil bahan baku industri (medis, pestisida, sabun, pupuk, pakan ternak, kayu, dsb) (Schmutterer 1988). Tanaman mimba di Indonesia pada umumnya tumbuh liar dan belum banyak dimanfaatkan. Petani kurang menaruh perhatian terhadap keberadaan tanaman mimba yang tumbuh liar tersebut.

Biji dan daun mimba mengandung empat senyawa kimia alami yang aktif sebagai pestisida, yaitu azadirakhtin, salanin, meliatriol, dan nimbin. Dalam satu gram biji mimba mengandung 2-4 mg azadirakhtin, namun ada juga yang mencapai $9 \mathrm{mg}$. Senyawa kimia tersebut dapat berperan sebagai penghambat pertumbuhan serangga, penolak makan, dan repelen bagi serangga. Disamping itu terdapat 20 senyawa lain yang peranannya sebagai pestisida belum jelas. Sebagai insektisida, mimba efektif membunuh lebih dari 200 jenis serangga hama dan relatif sulit menimbulkan resistensi dibanding dengan insektisida kimia sintetik (Khana 1992). Keuntungan lainnya, azadirakhtin mudah terabsorbsi oleh tanaman, bekerja secara sistemik, sedikit racun kontak dan aman bagi serangga musuh alami (Isman 1994).

Pestisida dari biji mimba dapat diproduksi baik dengan teknologi yang sederhana maupun dengan teknologi tinggi. Teknologi sederhana adalah dengan cara menumbuk atau menggiling biji mimba menjadi serbuk, kemudian serbuk direndam dalam air selama semalam, disaring dan langsung dapat diaplikasikan. Teknologi tinggi adalah dengan mengisolasi bahan aktif yang bersifat toksik dan diformulasi dengan menambahkan bahan-bahan lain, sehingga dapat diaplikasikan seperti insektisida pada umumnya. Pemanfaatan secara sederhana telah dipraktikan pada budidaya kapas di Lamongan (Nurindah et al. 2004).

\section{EFEKTIVITAS INSEKTISIDA EKSTRAK BIJI MIMBA TERHADAP SERANGGA HAMA KAPAS DAN MUSUH ALAMINYA}

Insektisida botani biji mimba, baik dalam formulasi serbuk maupun cair, efektif sebagai penekan populasi $H$. armigera, aman terhadap musuh alami, dan dapat diterima oleh petani. 
Pengujian efektivitas insektisida ekstrak biji mimba pada hama sasaran pengerek buah $H$. armigera telah dilaksanakan melalui beberapa tahapan penelitian, yaitu penelitian laboratorium, lapangan pada skala sempit, hingga lapangan pada skala luas dengan melibatkan petani (Sunarto et al. 2002; 2004; 2007).

Hasil pengujian di laboratorium menunjukkan bahwa insektisida EBM dalam formulasi serbuk kasar (SBM), serbuk halus (WP), dan cair (EC) efektif membunuh larva dan menghambat perkembangan $H$. armigera yang lolos dari kematian saat fase larva (Subiyakto et al. 1996; 1999, Sunarto et al. 2005). Mortalitas larva yang terjadi diduga disebabkan oleh senyawa toksik azadirakhtin, yang merupakan kandungan utama biji mimba. Azadirakhtin dalam sistem metabolisme serangga dapat mengganggu sel neurosekretori yang akhirnya berakibat adanya gangguan pada stimulasi protein dan pengaturan metamorfosa. Gangguan yang berat akan menyebabkan mortalitas larva, sedang gangguan yang ringan menyebabkan pertumbuhan terhambat (Mordue \& Blackwell 1993). Efektivitas formulasi EC lebih tinggi dibanding formulasi SBM dan WP. Formulasi EC untuk membunuh 50\% larva $H$. armigera dibutuhkan konsentrasi yang lebih rendah yaitu 3,06 ml/1 air atau setara dengan 3,8 gr biji mimba, sedangkan pada formulasi
WP sebesar 7,53 g/1 air dan SBM sebesar 12,28 g/1 air (Tabel 1).

Formulasi EC merupakan formulasi pestisida biji mimba yang dihasilkan melalui ekstraksi dengan menggunakan pelarut organik, sedangkan formulasi SBM dan WP menggunakan pelarut air. Senyawa aktif yang terkandung dalam mimba umumnya mempunyai sifat mudah larut dalam pelarut organik, sehingga bahan aktif yang terlarut diduga lebih tinggi dibanding dengan pelarut air.

Insektisida EBM formulasi serbuk kasar telah diuji di lapangan dan didapatkan bahwa EBM dapat menjadi substitusi insektisida kimia sintetik (Subiyakto et al. 1996). Hasil pengujian efektivitas EBM di pertanaman kapas terhadap $H$. armigera menunjukkan bahwa EBM tidak berbeda dengan pestisida botani komersial yang berbahan aktif azadirakhtin 1\% (NeemAzal) dan aman terhadap musuh alami (Sunarto et al. 2002). Populasi larva $H$. armigera yang dikendalikan dengan SBM 15 gr/1 air lebih rendah dibandingkan dengan populasi $H$. armigera pada tanaman kapas yang dikendalikan dengan insektisida kimia sintetik berbahan aktif asefat dan deltametrin (Gambar 1). Selain itu, perpaduan antara aplikasi SBM sebanyak 3 kali dengan pelepasan parasitoid telur Trichogrammatoidea armigera sebanyak 2 kali dosis 100.000 parasitoid/ha/pelepasan dapat mening- 
katkan produktivitas kapas berbiji didukung oleh hasil penelitian di hingga 20\% dan menghemat biaya laboratorium. Pengujian EBM pengendalian hama sebesar $61 \%$ formulasi cair di laboratorium (Hadiyani et al. 2003). menunjukkan bahwa EBM termasuk

Rendahnya populasi larva $H$. dalam kriteria aman terhadap imago armigera pada pertanaman kapas yang parasitoid telur Trichogrammatoidea dikendalikan dengan SBM, selain armigera dan Trichogramma chilonis karena efektivitasnya dalam (Sunarto et al. 2004; Sunarto et al. membunuh, juga dibantu oleh 2007). Selain itu, telah banyak keberadaan populasi kompleks predator dilaporkan bahwa insektisida dengan yang pada umumnya lebih tinggi bila bahan aktif senyawa dari eksktrak dibandingkan pada pertanaman kapas mimba tidak berbahaya untuk laba-laba yang dikendalikan dengan insektisida (Mann \& Dhaliwal 2001), Chrysoperla kimia sintetik (Gambar 2). Hal ini carnea (Praveen \& Dhondapani 2001, menunjukkan bahwa SBM aman bagi Gandhi et al. 2005), tidak berpengaruh kehidupan musuh alami. Fakta ini juga

Tabel 1. $\mathrm{LC}_{50}$ beberapa jenis formulasi pestisida botani biji mimba terhadap larva $H$. armigera

\begin{tabular}{cc}
\hline \hline Formulasi pestisida & $\mathbf{L C}_{\mathbf{5 0}}$ \\
\hline SBM & $12,28 \mathrm{~g} / 1$ air \\
WP & $7,53 \mathrm{~g} / 1$ air \\
EC & $3,06 \mathrm{ml} / 1$ air \\
\hline
\end{tabular}

Sumber: (Sunarto et al. 2002)

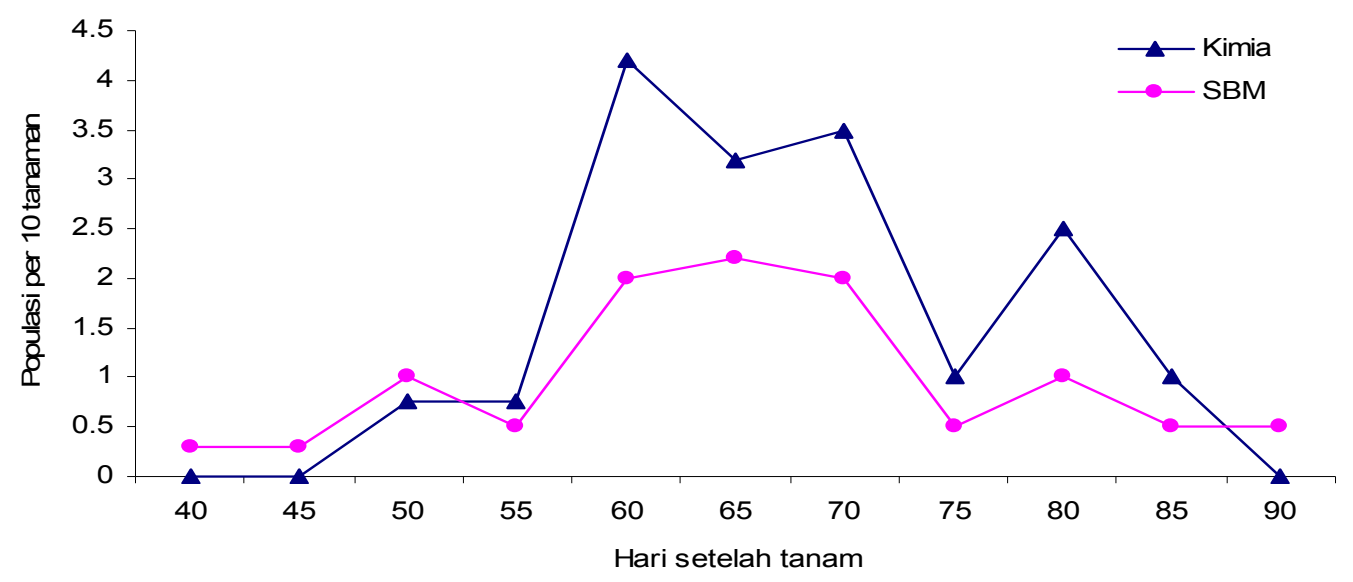

Gambar 1. Pengaruh SBM dan insektisida sintetik (asefat \& deltametrin) terhadap populasi $H$. armigera di pertanaman kapas Asembagus, Situbondo (Nurindah et al. 2004). 


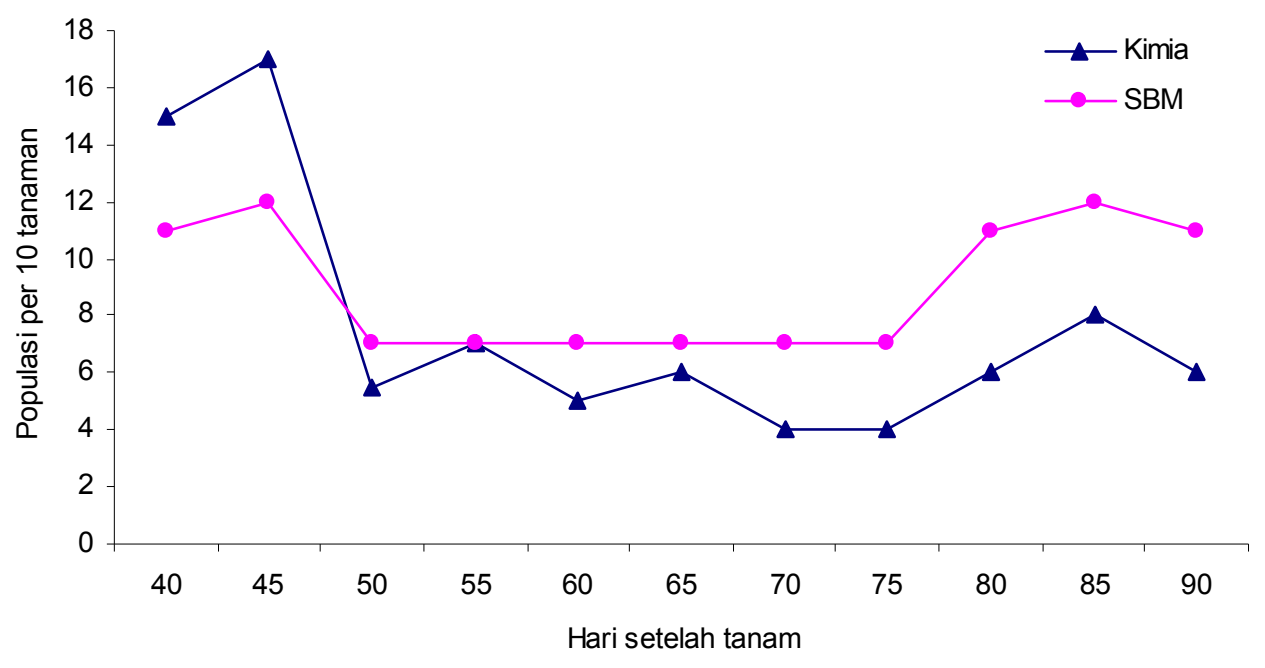

Gambar 2. Pengaruh SBM dan insektisida sintetik (asefat \& deltametrin) terhadap populasi kompleks predator di pertanaman kapas Asembagus, Situbondo (Sunarto et al. 2002).

terhadap aktivitas parasitisasi Tindakan konservasi musuh alami Diaeretiella rapae terhadap Myzus serangga hama kapas dapat dilakukan persicae (Lowery \& Isman 1995). dengan menanam varietas tahan, Selain itu, ekstrak mimba juga tidak menerapkan sistem tumpangsari mempunyai efek negatif terhadap dengan palawija, pemanfaatan parasitoid larva Plutella xylostella, jerami/serasah sebagi mulsa, yaitu Diadromus collaris (Gravenhorst) menerapkan ambang kendali dengan dan bahkan mempunyai efek sinergis mempertimbangkan musuh alami, serta terhadap parasitasi Cyrtopeltis plutellae (Kraees \& Cullen 2008; Charleston et al. 2005). Berdasarkan kenyataankenyataan ini dapat dinyatakan bahwa EBM cukup aman bagi musuh alami dan dapat dipadukan dalam pengendalian hayati.

\section{IMPLEMENTASI PENGGUNAAN INSEKTISISDA EBM DALAM KONSERVASI MUSUH ALAMI}

Kunci keberhasilan pengendalian hama terpadu (PHT) kapas adalah konservasi musuh alami serangga hama (Nurindah \& Sunarto 2008b). menggunakan insektisida botani, jika diperlukan. Tambahan tindakan pengendalian dengan menggunakan insektisida kimia sintetik biasanya tidak diperlukan, jika komponenkomponen tersebut diterapkan secara konsisten,

Kendala utama konservasi musuh alami pada tanaman kapas adalah perilaku petani yang spray minded. Sebenarnya petani telah menerapkan beberapa teknik budidaya yang dapat mengkonservasi musuh alami yaitu menanam varietas tahan, menerapkan 
sistem tumpangsari dengan palawija dan pemanfaatan jerami/serasah sebagi mulsa. Namun demikian, penyemprotan insektisida bagi petani masih diyakini sebagai sebuah keharusan dan dianggap sebagai jaminan keberhasilan usahatani kapas. Pola pikir penyemprotan insektisida yang intensif berdampak terhadap berkurangnya atau hilangnya peran cara budidaya yang dapat mengkonservasi musuh alami yang selama ini sudah diterapkan. Kalaupun petani menggunakan ambang kendali sebagai dasar penyemprotan, keberadaan musuh alami belum diperhitungkan, sehingga biasanya keputusan penyemprotan terjadi setiap periode pengamatan atau tidak berbeda dengan penyemprotan secara berjadwal, terutama pada puncak populasi $H$. armigera pada umur 55 80 hari setelah tanam. Padahal, ambang kendali dengan memperhitungkan keberadaan musuh alami dapat menekan atau bahkan meniadakan penggunaan insektisida tanpa mengurangi produktivitas yang nyata (Nurindah \& Sunarto 2008).

Ambang kendali merupakan komponen PHT yang paling sulit diterima oleh petani, apalagi ambang kendali dengan mempertimbangkan musuh alami. Dari hasil kegiatan diseminasi introduksi teknologi PHT kapas di Kabupaten Lamongan, Jawa Timur diketahui bahwa kemauan petani untuk menerapkan ambang kendali sebelum dan setelah kegiatan tidak berubah yaitu $0 \%$, padahal pengetahuan petani tentang ambang kendali meningkat dari $0 \%$ sebelum kegiatan menjadi $40 \%$ setelah kegiatan (Tabel 2) (Basuki et al. 2006). Dalam prakteknya petani melakukan penyemprotan insektisida menggunakan "ambang rasa" yaitu penyemprotan menggunakan dasar perasaan petani atau suka-suka petani, sehingga biasanya petani cenderung lebih intensif dalam melakukan penyemprotan insektisida.

Properti EBM yang dapat menyebabkan mortalitas pada serangga-serangga fitofag dan relatif aman bagi musuh alami dapat digunakan sebagai 'alat' untuk konservasi musuh alami, atau dapat

Tabel 2. Respon petani terhadap teknologi PHT yang diintroduksikan sebelum dan sesudah diseminasi

\begin{tabular}{lcc}
\hline \hline \multirow{2}{*}{ Uraian } & \multicolumn{2}{c}{ Respon petani (\%) } \\
\cline { 2 - 3 } & Sebelum & Sesudah \\
\hline Pengetahuan tentang serangga hama kapas & 6 & 30 \\
Pengetahuan tentang musuh alami & 0 & 30 \\
Pengetahuan tentang ambang kendali & 0 & 40 \\
Kemauan untuk menerapkan ambang kendali & 0 & 0 \\
\hline Sumber: (Basuki et al. 2006) & &
\end{tabular}


dikatakan EBM merupakan komponen PHT yang dapat digunakan dalam pengendalian hayati melalui konservasi musuh alami (conservation biological control, $C B C$ ). Tujuan dari $\mathrm{CBC}$ adalah untuk memodifikasi lingkungan sehingga kelimpahan dan aktivitas agens hayati dapat ditingkatkan dan pengelolaan hama dapat diperbaiki (Naranjo \& Elseworth 2009). Walaupun demikian, banyak faktor yang menyebabkan suatu agroekosistem tidak sesuai untuk perkembangan musuh alami, sehingga fungsinya sebagai faktor mortalitas biotik bagi serangga hama berkurang. Faktor-faktor tersebut antara lain adalah penggunaan insektisida berspektrum luas (DeBach \& Hagen 1964; Croft 1990). Dalam pengelolaan hama, dimana pemanfaatan agens hayati dan insektisida masih diperlukan untuk menekan populasi hama, maka pemilihan insektisida yang selektif dapat meminimalkan pengaruh negativ insektisida terhadap musuh alami (Croft 1990; Johnson dan Tabashnik 1999). Oleh karena itu, EBM merupakan salah satu insektisida selektif yang dapat digunakan untuk pengendalian hama, tetapi juga mengkonservasi musuh alami.

Peran insektisida EBM sebagai agens pengendali hama berpeluang besar untuk dapat diterima oleh petani yang "spray minded", karena dapat berfungsi sebagai substitusi insektisida kimia sintetis. Sebagai insektisida yang direkomendasikan dalam sistem pengelolaan serangga hama kapas, maka penggunaan insektisida EBM selain sebagai agen pengendali, sekaligus memberikan ketenangan kepada petani yang memiliki keyakinan bahwa penyemprotan insektisida sebagai jaminan keberhasilan usahatani kapas. Meskipun secara ekonomi hal tersebut termasuk pemborosan biaya, karena jika komponen PHT kapas diterapkan dengan benar kemungkinan besar tidak diperlukan penyemprotan insektisida (Nurindah \& Sunarto 2008b), namun untuk tujuan konservasi musuh alami hal tersebut dapat tercapai. Selain itu, biaya pengendalian hama dengan insektisida EBM lebih murah dibanding jika petani menerapkan penyemprotan dengan insektisida kimia sinetetik (Nurindah \& Mukani 2006). Pestisida berbahan aktif senyawa-senyawa dari ekstrak tanaman mimba juga telah direkomendasikan dalam strategi pengelolaan serangga hama di India, karena terbukti efektif dalam mengendaliakn penggerek buah kapas, aman bagi lingkungan dn tidak menimbulkan resurgensi pada Bemisia spp. (Saxena 1999). Oleh karena itu, insektisida EBM diharapkan dapat dijadikan sebagai "target antara" untuk membebaskan usahatani kapas dari insektisida kimia sintetik, terutama yang berspektrum luas. 


\section{KESIMPULAN}

Musuh alami di agro-ekosistem kapas merupakan agens hayati yang dapat dimanfaatkan untuk mengendalikan populasi serangga hama jika populasinya berkembang dengan baik. Populasi musuh alami dapat dikonservasi jika pada agroekosistem kapas tidak dilakukan penyemprotan insektisida kimia sintetik. Ekstrak biji mimba (EBM) merupakan insektisida botani yang dapat dimanfaatkan untuk mengendalikan serangga hama kapas dan juga untuk melestarikan musuh alami. Penggunaan EBM merupakan usaha strategis untuk pertanian kapas yang masih 'spray minded'.

\section{DAFTAR PUSTAKA}

Anonim 2009. AS perluas kapas di Indonesia. Bisnis Indonesia online, Rabu, 3 Juni 2009. http://web.bisnis.com/edisicetak/edisi-

harian/perdagangan/1id120409.ht ml.

Basuki T, Nurindah, Wahyuni SA. 2006. Persepsi petani terhadap introduksi teknologi PHT kapas di lahan sawah sesudah padi Kabupaten Lamongan. Prosiding Lokakarya Revitalisasi Agribisnis Kapas Diintegrasikan dengan Palawija di Lahan Sawah Tadah Hujan, Lamongan 8 September 2005, p: $140-145$.

Charleston DS, Kfir R, Dicke M, Vet LEM. 2005. Impact of botanical pesticides derived from Melia azedarach and Azadirachta indica on the biology of two parasitoid species of diamondback moth. Biol Contr, 33: $131-142$.

Croft BA. 1990. Arthropods Biological Control Agents and Pesticides. John Valley and Sons, New York.

DeBach P, Hagen KS. 1964. Manipulations of entomophagous species. In DeBach, P. (Ed.), Biological Control of Insect Pests and Weeds. Reinhold, New York, p: $1-8$.

Gandhi PI, Gunasekaran K, Poonguzhali S, Anandham R, Kim Gil-Hah, Chung KeunYook and Sa T. 2005. Laboratory evaluation of relative toxicities of some insecticides Against Trichogramma chltonis (Hymenoptera:

Trichogrammatidae) and Chrysoperla carnea (Neuropterai Chrysopidae). Journal of Asia Pacific Entomology, 8(4): 381386

Hadiyani S, Sunarto DA, Gothama AAA. Wahyuni SA 2003. Perbaikan rekomendasi paket PHT untuk pengendalian Helicoverpa armigera Hbn. Pada tanaman kapas. Jurnal Tanaman Industri (92): $63-69$.

Isman MB. 1994. Botanical insecticides, detterents and repellents in modern agriculture and increasingly regulated world. Annual Review of Entomology, 51: $45-66$.

Johnson MT, Tabashnik BE. 1999. Enhanched biological control through selectivity. In Bellows, T. S. and Fisher, T. W. (Eds.), Handbook of Biological Control, Academic Press, New York. p: $297-317$. 
Khana A. 1992. Neem compounds commercialized. Biotechnology and Development Monitor, No. 13, December 1992.

Kraees H, Cullen EM. 2008. Insect growth regulator effects of azadirachtin and neem oil in survivorship, development and fecundity of Aphis glycine (Homoptera: Aphididae) nd its predator, Harmonia axyridis (Coleoptera: Coccinellidae). Pest Management Science, 64: 660 668.

Lowery DT, Isman MB. 1995. Toxicity of neem to natural enemies of aphids. Phytoparasitica, 23 (4): 297-306.

Mann GS, Dhaliwal GS. 2001. Impact of neem-based insecticides on beneficial arthropods in cotton ecosystem. Annals of Plant Protection Sciences. 2001, 9: 2, 225-229.

Mordue AJ, Blackwell A. 1993. Azadirachtin: an update. Journal of Insect Physiology, 39(11): 903 $-924$.

Naranjo S, Elseworth PC. 2009. The contribution of conservation biological control to integrated control of Bemisia tabaci in cotton. Biol Contr 51: 458 - 470.

Nurindah dan Sunarto DA. 2008a. Ambang kendali penggerek buah kapas Helicoverpa armigera dengan mempertimbangkan keberadaan predator kapas. Jurnal Penelitian Tanaman Industri, Volume 14, Nomor 2: $72-77$.

Nurindah dan Sunarto DA. 2008 b. Konservasi musuh alami serangga hama sebagai kunci keberhasilan PHT kapas. Perspektif: Volume 7 Nomor 7: 1 -11 .

Nurindah dan Indrayani IGAA. 2002. Musuh alami serangga hama kapas. Monograf Balittas No. 7: Kapas, Buku 2: 144 - 158.

Nurindah dan Mukani. 2006. Peningkatan daya saing agribisnis kapas dengan PHT di lahan sawah tadah hujan. Prosiding Lokakarya Revitalisasi Agribisnis Kapas Diintegrasikan dengan Palawija di Lahan Sawah Tadah Hujan, Lamongan 8 September 2005, p: $35-42$.

Nurindah, Sunarto DA, Sujak. 2004. Pengaruh penyemprotan insektisida terhadap prekembangan populasi laba-laba dan wereng kapas Amrasca biguttulla (Ishida) (Homoptera: Ciccadelidae). Prosiding Lokakarya Pengembangan Kapas Dalam Rangka Otoda, Malang, 15 Oktober 2002, p: $62-66$.

Nurindah, Parmono DH, Sujak. 2006. Faktor mortalitas biotik Helicoverpa armigera (Hubner) pada kapas tumpangsari dengan kedelai. Prosiding Lokakarya Revitalisasi Agribisnis Kapas Diintegrasikan dengan Palawija di Lahan Sawah Tadah Hujan, Lamongan 8 September 2005, p: $110-117$.

Praveen PM, Dhandapani N. 2001. Eco-friendly management of major pests of okra (Abelmoschus esculentus (L.) Moench). Journal of Veg Crop Prod. 2001, 7: 2, 312

Saxena RC. 1999. Neem in the management strategies of insect 
pest of cotton. In Gupta, G., Katiyar, K. N., Kirti-Sharma,and Sharma, K. Singh, R.P. (ed.), Azadirachta indica A. Juss, $\mathrm{p}: 177-189$.

Schmutterer H. 1988. Potential of azadirachtin-containing pesticides for integrated pest control in developing and industrialized countries. Journal of Insect Physiology, 34(7): 713 - 719.

Subiyakto, Dwi Winarno, Diwang HP. 1999. Pengaruh konsentrasi serbuk biji mimba (Azadirachta indica A. Juss) terhadap aspek biologi ulat daun tembakau Spodoptera litura (F.). Prosiding Semiloka Teknologi Tembakau. Balittas. 133-139.

Subiyakto, Dwi Winarno, Diwang HP. 1996. Pengaruh konsentrasi serbuk biji mimba (Azadirachta indica A. Juss.) terhadap aspek biologi ulat daun tembakau Spodoptera litura (F). Prosiding Semiloka Teknologi Tembakau. Balittas. 127-132.

Sunarto DA, Nurindah, Sujak. 2004. Pengaruh ekstrak biji mimba terhadap konservasi musuh alami dan populasi Helicoverpa armigera Hubner pada tanaman kapas. Jurnal Penelitian Tanaman Industri, 10 (3): 89 95.
Sunarto DA, Nurindah, Karindah S. 2007. Pengaruh ekstrak bji mimba terhadap parasitoid telur Trichogrammatoidea armigera Nagaraja (Hymenoptera: Trichogrammatidae). Prosiding Lokakarya Nasional Kapas dan Rami, Surabaya, 15 Maret 2006, p: $99-103$.

Sunarto DA, Subiyakto, Winarno D. 2002. Pengaruh penambahan ajuvan pada insektisida nabati serbuk biji mimba (Azadirachta indica A. Jussieu) terhadap efektivitasnya dalam pengendalian hama pada tanaman kapas. Prosiding Lokakarya Nasional Pertanian Organik, Malang, 7-9 Oktober 2002, Universitas Brawijaya, Malang. 106-112.

Sunarto DA, Subiyakto, Winarno D, Hadiyani S, Sujak. 2005. Toksisitas beberapa formulasi pestisida botani mimba (Azadirachta indica A. Jussieu) terhadap Helicoverpa armigera Hbn. dan Spodoptera litura F. Prosiding Seminar Nasional Inovasi Teknologi dan Kelembagaan Agribisnis Tahun 2004. Pusat Penelitian dan Pengembangan Sosial Ekonomi Pertanian. 407-416. 